\section{A Serum that Discloses the Genotype of some Rh-Positive People}

The blood-group antigen $R h$, present in the red blood cells of about 85 per cent of normal people, called $R h$-positive, and absent in the rest, $R h$-negative, plays, with its corresponding anti- $R h$ agglutinin, an important part in the causation of erythroblastosis fœtalis, a familial disease of the new-born. In about 90 per cent of cases of the disease the mother is $R h$ negative and has made anti- $R h$ which passes through the placenta and damages the red blood cells of her $R h$-positive foetus. The $R h$ factor is inherited as a dominant character with three genotypes $R h R h$, Rhrh and $r h r h$.

Recently we have found in the serum of the $R h$ positive mother of an erythroblastotic baby an agglutinin capable of disclosing the genotype of some $R h$-positive people. This serum, sent to us by Dr. A. J. MeCall as containing anti-Rh and yet being from an $R h$-positive mother, we call $S t$ from the first two letters of the mother's surname. It reacts with the blood of all $R h$-negative and of all heterozygous $R h$-positive persons, $R h r h$ (recognized by being $R h$ positive parents or children of $R h$-negative subjects), but it fails to react with about 20 per cent of bloods all of which must, therefore, be homozygous, $R h R h$, and represent about half of the $R h$-positive homozygotes (about 38 per cent of the population). The $S t$ serum is somewhat similar to theanti-Hrserum found by Levine, Javert and Katzin, and referred to by Wiener ${ }^{1}$. The latter serum, like $S t$, reacted with all $R h$-negative bloods, but whereas $S t$ failed to react with only 20 per cent, the anti-Hr, apparently, failed with about 50 per cent of people ${ }^{2}$. Our findings with $S t$ serum, and family details, are given below.

$$
\begin{aligned}
& \begin{array}{lrrrrr} 
& & & S t+ & S t- & \text { Total } \\
\text { General population } & \ldots & \ldots & 173 & 45 & 218 \\
R h \text {-negative bloods } & . . & \ldots & 100 & 0 & 100 \\
R h \text {-positive heterozygous bloods } & 32 & 0 & 32
\end{array} \\
& \text { Mrs. St. } \quad \text { O.MN.Rh+. St- } \\
& \text { Mr. St. } \quad A_{1} \cdot M N . R h+. S t+ \\
& \text { Eldest son O.N.Rh+.St+. } \\
& \text { 2rd son Died of erythroblastosis fœtalis. } \\
& \text { 3rd son } \quad \text { O.MN. } R h+. S t+. \text { recovered from } \\
& \text { erythroblastosis fœtalis. }
\end{aligned}
$$

It follows that certain rules can be formulated concerning parentage in general :

(a) An St-negative child must have both parents $R h$-positive. (b) All children of an St-negative parent must be $R h$-positive.

In families with erythroblastosis fœetalis due to anti-Rh:

(1) All mothers and children must be St-positive. (2) The only member who can be $S t$-negative is the father. We have found no exception to these rules. (3) The father will be more frequently $S t$-negative, since he is always $R h$-positive, than will fathers of normal children. (4) If a father is $S t$-negative he must be homozygous, $R h R h$, and so cannot produce an $R h$ negative child. His chance of producing a child without the disease is, therefore, extremely remote. (5) If the great majority of fathers of erythroblastotic infants are homozygous, a conclusion to which we and our collaborators have been led by other observations $^{3}$, about half of them should be $S t$-negative. We have so far found eight out of twenty-one to be $S t$ negative. The examination of a larger number should show the extent of any preponderance of homozygous fathers.

There is ample evidence that there occur subgroups of $R h$ somewhat similar to those of the $A B O$ system of groups, and to explain the findings that have been reported ${ }^{1-4}$, it is certainly necessary to postulate three allelomorphic genes $\left(R h_{1}, R h_{2}\right.$ and $\left.r h\right)$ and almost certainly four $\left(R h_{1}, R h_{2}, R h_{3}\right.$ and $\left.r h\right)$. It is tempting to equate the frequency of the genotype $R h_{1} R h_{1}$ to $0 \cdot 20$, the proportion of people whose cells fail to react with the $S t$ serum. If the frequency of the gene $R h_{1}$ is so derived, it may be estimated that people of the genotypes $R h_{2} R h_{2}$ and $R h_{2} r h$ form about one sixth of all $R h$-positive persons. It is noteworthy also that Wiener ${ }^{1}$, frcm the behaviour of an anti- $R h$ serum that failed to react with about 16 per cent of $R h$-positive bloods, thought that one sixth of all $R h$-positives belonged to the 'subtype' $R h_{2}$.

R. R. RACE.

G. L. TAYLOR.

Galton Laboratory Serum Unit,

Medical Research Council,

Emergency Public Health Laboratory Service. Aug. 17

${ }^{1}$ Wiener, Amer. J. Clin. Path., 12, 302 (1942).

${ }^{2}$ Levine, Katzin, Vogel and Burnham, in "Blood Substitutes and Blood Transfusion", p. 317 (Springfield, Illinois: Mudd and Thalhimer, 1942).

${ }^{3}$ Race, Taylor, Cappell and McFarlane, Brit. Med. J. (in the press). - Levine, J. Hered., 34, 71 (1943).

\section{Vitamin C Requirements of the Syrian Hamster}

WHILE engaged in some endocrinological and immunological work on the Syrian hamster, we became interested in the diet of this animal. It was thought of interest to examine the ascorbic acid requirements of the hamster, because if the animal required this vitamin, the hamster might be a useful animal for vitamin $\mathrm{C}$ studies since it reproduces and matures so rapidly, and is susceptible to many infections not easily produced in other animals. Since we started this study, Routh and Houchin ${ }^{1}$ have concluded that thiamin, riboflavin, pyridoxin, pantothenic acid and nicotinic acid are essential in the diet of the hamster, while Cooper, Waisman and Elvehjem ${ }^{2}$ have concluded that biotin and possibly inositol and $p$-aminobenzoic acid, in addition to thiamin, riboflavin, pantothenic acid, pyridoxin, and choline, are essential to the hamster, but that nicotinic acid and ascorbic acid are not. Since no growth curves have been published, we think the present study would be of interest.

The experiments were limited to the single substance ascorbic acid, using a diet containing adequate amounts of other growth essentials.

Procedure: Twenty male hamsters 3-5 weeks old were obtained from a commercial dealer (Henry Bergman, Springfield, Missouri). They were divided into two groups of ten each and of equal weight distribution, average body weight $42 \mathrm{gm}$., and fed ad libitum on a diet with and without added ascorbic acid. The diet was of the following composition :

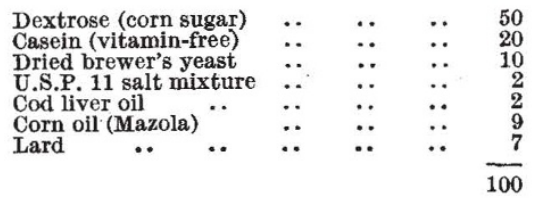

